\title{
Project Pró-Natal: Population-based Study of Perinatal and Infant Mortality in Natal, Northeast Brazil
}

\author{
Ana Maria O. Ramos, ${ }^{1}$ Técia D.O. Maranhão, ${ }^{1}$ Albanita S. Macedo, ${ }^{1}$ \\ Jon I. POLLOCK, ${ }^{2}$ AND Alan M. EMONd ${ }^{2 *}$ \\ 1 Universidade Federal do Rio Grande do Norte, Center for Health Sciences, Departments of Pathology and \\ Obstetrics, Av Nilo Peçanha 259, Petrópolis, 59012-300 Natal RN, Brazil \\ ${ }^{2}$ Institute of Child Health, Bristol Royal Hospital for Children, St. Michael's Hill, Bristol BS2 8BJ, UK
}

Received September 1, 1998; accepted February 16, 1999.

\begin{abstract}
The Pró-Natal project is a collaborative initiative that aims to improve maternal and infant health in a deprived community in Natal, Northeast Brazil. To assess the perinatal and infant mortality in this population of 40,000 , we have collected over a 2-year period a consecutive series of 39 autopsy examinations on deaths under 1 year of age. During this period there were 2212 live births in the study population. The 14 perinatal deaths are described using the Wrigglesworth classification, and the 25 infant deaths, using a clinicopathological system.

The contribution of normally formed stillbirths was small (14\%), which probably reflects the underreporting of stillbirths in this community. The most common cause of death in the live births was complications of prematurity $(43 \%)$. Specific causes $(22 \%)$ of perinatal deaths were predominantly infections, including one case of congenital syphilis. Perinatal asphyxia was diagnosed in $14 \%$, and there was one case (7\%) of a chromosome abnormality. Infant deaths were predominantly due to respiratory $(45 \%)$ and gastrointestinal infections $(28 \%)$, with chronic malnutrition as an underlying cause in $80 \%$ of cases.

Prenatal care could theoretically have prevented three of the perinatal deaths, and a further six deaths could have been avoided by improved management of labor and the immediate neonatal period. Prevention of malnutrition and improved treatment of acute infections would contribute to a reduction in infant mortality in
\end{abstract}

*Corresponding author this population. The Pró-Natal project will use these data to design preventative interventions to reduce perinatal and infant mortality in this community.

Key words: infant mortality, perinatal mortality, autopsy, malnutrition

\section{INTRODUCTION}

The Pró-Natal project is a collaborative initiative between Universidade Federal do Rio Grande do Norte (UFRN), Brazil, and University of Bristol, England, and is based in the community of Felipe Camarão in the West District of the city of Natal, Rio Grande do Norte, one of the poorest states of Northeast Brazil. The study population is composed of approximately 40,000 residents of the geographically defined area of the bairro of Felipe Camarão. The birth rate is approximately 1100/ year. The residents live in a poor urban setting, on the edge of the city of Natal, and health care is provided from one polyclinic and one health center in the community. The overall aim of the project is to implement and evaluate a community-based health care program for women and children to reduce maternal and infant mortality.

It is recognized that the maternal and infant mortality in this district is high, but accurate figures on the numbers and causes of deaths were not available at the start of the project. One of the 
first specific objectives of the project was to undertake a baseline survey of perinatal and infant deaths, to discover why children were dying, which deaths were preventable, and to plan communitybased interventions to reduce mortality. A similar exercise is currently being undertaken to assess morbidity in children from the project district. This report describes a series of consecutive postmortem examinations of children under 1 year of age from Felipe Camarão.

\section{METHODS}

At the start of the project, considerable publicity was given to the local population (utilizing clinic staff, community health agents, and local community leaders) of the need to register all deaths of newborn babies. Thereafter, the parents of all known infants who died at the age of $<1$ year were approached, and permission sought for postmortem examination. All autopsies were undertaken by the same team, from the UFRN Pathology Department, working in the S.V.O. (service for the verification of cause of death), using a standard method to identify the cause of death and associated factors. All cases were submitted for microscopic examination, using hematoxylin and eosin (H\&E) stain and other special techniques as required. The deaths were classified according to clinicopathological systems, the perinatal group using the Wigglesworth classification [1], and the infant group using a morphological system.

Because of the lack of technical support, it was not possible to undertake bacteriological, virological, genetic, or biochemical analyses of postmortem specimens. The following external morphological characteristics were used to define malnutrition at postmortem: reduction in subcutaneous fat and muscle bulk, reduction in facial fat pads, shrunken eyes, brittle or discolored hair, and peripheral edema. Microscopic features of malnutrition were atrophy of the thymus, atrophy or fatty change in the liver, and pancreatic fibrosis. Most cases of malnutrition were marasmic in type, but the presence of characteristic skin and hair changes, peripheral edema, and fatty infiltration of the liver was labeled as kwashiorkor. Background information on all deaths submitted to autopsy was obtained from clinic notes, and from a structured interview carried out with the mother.
Data on the total number of births and deaths to residents of the community of Felipe Camarão were obtained from the information system (SINASC) of the municipal department of health in Natal, which collects information from the registration of births and deaths. Although this is required by law, there is considerable underregistration in poor communities in the city. To estimate the scale of underregistration, specific questions were asked women of reproductive age as part of a representative community questionnaire survey (A.M. Emond, N.D.L. Costa, M.G. Morais, J.I. Pollock, unpublished results) carried out in 1995.

\section{RESULTS}

During the period September 1993-October 1995, there were 2212 live births to residents of the study area. Twenty percent of the mothers were teenagers, and less than half received any antenatal care. In the live births, the rate of low birthweight $(<2500 \mathrm{~g})$ was $8.5 \%$, and the rate of prematurity $(<37$ weeks) was $5.5 \%$. The community survey revealed that only $60 \%$ of perinatal and infant deaths were registered. We estimate that, during the same 2-year period, at least 60 liveborn children died under the age of 1 year, an estimate based on registered deaths with an allowance for $40 \%$ underreporting. Permission for postmortem examination was obtained in 39 cases (14 deaths in the early perinatal period, and 25 postnatal deaths up to 12 months).

\section{Perinatal deaths}

Two children were stillborn and 12 were liveborn, surviving between a few minutes and 5 days. The details are summarized in Table 1. Both stillborn fetuses $(14 \%)$ were normally formed, one being macerated and the other fresh. Of the liveborn infants, one had the appearance of a lethal chromosome abnormality (case 10). Five were extremely preterm ( $<28$ weeks), and five were thought to be $<37$ weeks gestation, although accurate dating of the pregnancies with ultrasound was not available. Six of the preterm infants died from complications of immaturity ( $43 \%$ of total). Specific causes (22\%) included two babies with pneumonia, although the causative organism could not be identified, and one with classical signs of congenital syphilis. Two (14\%) liveborn full-term infants of normal birth 
Table 1. Data on 14 perinatal deaths

\begin{tabular}{|c|c|c|c|c|c|}
\hline Case & Sex & $\begin{array}{l}\text { GA } \\
\text { (weeks) }\end{array}$ & $\begin{array}{l}\text { Birth } \\
\text { weight } \\
(\mathrm{g})\end{array}$ & Age & Diagnosis \\
\hline 1 & M & 22 & 500 & Min & $\begin{array}{l}\text { Extreme imma- } \\
\text { turity }\end{array}$ \\
\hline 2 & $\mathrm{~F}$ & 24 & 620 & $8 \mathrm{~h}$ & $\begin{array}{l}\text { Hyaline mem- } \\
\text { brane disease }\end{array}$ \\
\hline 3 & $\mathrm{~F}$ & 26 & 1466 & $1 \mathrm{~h}$ & $\begin{array}{c}\text { Congenital } \\
\text { syphilis }\end{array}$ \\
\hline 4 & M & 28 & 2430 & $9 \mathrm{~h}$ & $\begin{array}{l}\text { Hyaline mem- } \\
\text { brane disease }\end{array}$ \\
\hline 5 & M & 24 & 1890 & $5 \mathrm{~min}$ & $\begin{array}{l}\text { Extreme imma- } \\
\text { turity }\end{array}$ \\
\hline 6 & $\mathrm{~F}$ & Term & 2865 & $3 \mathrm{~h}$ & $\begin{array}{l}\text { Pneumonia } \\
\text { Perinatal anoxia }\end{array}$ \\
\hline 7 & $\mathrm{~F}$ & 33 & 1518 & 3 days & Pneumonia \\
\hline 8 & $\mathrm{~F}$ & 25 & 960 & $3 \mathrm{~h}$ & $\begin{array}{l}\text { Extreme imma- } \\
\text { turity } \\
\text { Hemorrhagic } \\
\text { disease }\end{array}$ \\
\hline 9 & $\mathrm{~F}$ & Term & 3000 & Stillbirth & $\begin{array}{l}\text { Intrauterine } \\
\text { anoxia }\end{array}$ \\
\hline 10 & $\mathrm{~F}$ & 36 & 1783 & $5 \mathrm{~min}$ & Patau syndrome \\
\hline 11 & $\mathrm{~F}$ & Term & 3725 & 3 days & $\begin{array}{l}\text { Meconium aspi- } \\
\text { ration syn- } \\
\text { drome }\end{array}$ \\
\hline 12 & $\mathrm{~F}$ & - & 1941 & Min & Perinatal anoxia \\
\hline 13 & $\mathrm{~F}$ & 33 & 2310 & 5 days & $\begin{array}{l}\text { Hemorrhagic } \\
\text { disease }\end{array}$ \\
\hline 14 & M & Term & 3089 & Stillbirth & $\begin{array}{l}\text { Intrauterine } \\
\text { anoxia } \\
\text { Maternal } \\
\text { eclampsia }\end{array}$ \\
\hline
\end{tabular}

weight died of the effects of perinatal asphyxia. The mother of one of these infants died after the infant was delivered (see below).

\section{Maternal deaths}

During the year 1995, four maternal deaths occurred among residents of Felipe Camarão, three related to hypertension and one to uterine perforation after an illegal abortion. In one of the cases of severe eclampsia, the infant was delivered stillborn by cesarean section prior to the death of the mother and is in our series (case 14). The details of the mothers of the other perinatal deaths are summarized in Table 2, from which it can be seen that most of the mothers were over the age of 20 , multigravidas, and without recognized health problems. Most (9/14) had attended one or more antenatal clinics, although few attended regularly. There were no maternal deaths postpartum.

\section{Infant deaths}

The 25 infants (11 male and 14 female) died at a median age of 6 months (range 1 to 12 months). Eleven $(44 \%)$ died at home, $2(8 \%)$ at the local polyclinic, and $12(48 \%)$ in various hospitals in the city. Many cases had several different concomitant diagnoses (Table 3). Infection was the principal cause of death, found in 20 cases (80\%). The main infection was bronchopneumonia (see Fig. 1), observed in 14 cases (56\%), followed by enteritis and colitis $(45 \%)$ and meningitis $(20 \%)$. There were two cases of lymphocytic pneumonia, a recognized presentation of AIDS in infants, but the HIV status of these children was not known. Urinary infection was diagnosed in one case.

In two cases (8\%), histological evidence was found of an underlying metabolic disorder (tyrosinemia and cystic fibrosis), which had not been diagnosed antemortem. Two cases of congenital heart disease $(8 \%)$ were observed (endocardial fibroelastosis and transposition of the great arteries). In 20 cases $(80 \%)$, there was evidence of chronic malnutrition, $15(75 \%)$ of which were marasmus (see Fig. 2) and 5 (25\%) were kwashiorkor/marasmus. Infestation with Ascaris lumbricoides was found in four cases (16\%), one of which had developed Loeffler's syndrome with larvae in the lung and liver. Two cases had cutaneous scabies. Candidiasis was observed in three cases, one in the esophagus and two in the small bowel, all of them in association with marasmus.

Data on breast feeding were retrospectively collected from the mothers of the infant deaths: four infants were never breast fed, six for one month or less, and eight for between two and six months. Feeding data were not available for the other seven cases. Many of the infants who died had a history of repeated minor infections, and the most common symptoms antemortem were fever, diarrhea, and vomiting.

\section{DISCUSSION}

This series is an attempt to review the causes of perinatal and infant death in a deprived, urban population in the Northeast of Brazil. In spite of 
Table 2. Data on mothers of fetuses and infants in Table 1

\begin{tabular}{|c|c|c|c|c|c|}
\hline Case & Age & Gravida/Para & Antenatal care & Mode of delivery & Other factors \\
\hline 1 & 29 & $\mathrm{G} 4 / \mathrm{P} 4$ & Yes, 4 visits & Vaginal & - \\
\hline 2 & 22 & $\mathrm{G} 3 / \mathrm{P} 2$ & No & Cesarean & Rubella \\
\hline 3 & 22 & G6/P5 & Yes, 6 visits & Vaginal & - \\
\hline 4 & 20 & $\mathrm{G} 3 / \mathrm{P} 2$ & Yes, 4 visits & Cesarean & Antepartum hemorrhage \\
\hline 5 & 22 & $\mathrm{G} 1 / \mathrm{P} 1$ & No & Vaginal & - \\
\hline 6 & 39 & $\mathrm{G} 4 / \mathrm{P} 4$ & No & Vaginal & - \\
\hline 7 & 22 & G6/P5 & Yes, 6 visits & Vaginal & - \\
\hline 8 & 19 & G4/P3 & Yes, 3 visits & Vaginal & Pneumonia \\
\hline 9 & 25 & $\mathrm{G} 2 / \mathrm{P} 2$ & Yes, 6 visits & Vaginal & - \\
\hline 10 & 26 & $\mathrm{G} 2 / \mathrm{P} 2$ & Yes, ? visits & Vaginal & - \\
\hline 11 & 28 & $\mathrm{G} 4 / \mathrm{P} 4$ & Yes & Vaginal & - \\
\hline 12 & $?$ & $?$ & No & Vaginal & Delivery without assistance \\
\hline 13 & 23 & G5/P5 & Yes & Cesarean & - \\
\hline 14 & 18 & $\mathrm{G} 1 / \mathrm{P} 1$ & No & Cesarean & Maternal death (eclampsia) \\
\hline
\end{tabular}

every effort to encourage registration of deaths, the series is clearly not complete. The reasons for under-registration of deaths in this community include the following: people don't want to pay the death registration fee, official cemeteries sometimes accept bodies for burial without death certificates, and clandestine cemetaries offer a cheap alternative for the disposal of bodies. Postmortem examination is not obligatory by law, and many families refuse permission for autopsy, even though there is no charge to them. In our series, there is particularly an under-representation of stillbirths in the cases referred for autopsy, and this reflects the attitude of health professionals toward the value of postmortem examinations of stillbirths and placentas. The lack of technical support for autopsies was particularly apparent in the area of cytogenetics, as the diagnosis of chromosomal abnormality had to be based on morphology alone. Facilities for biochemical analysis would have been helpful in confirming that tyrosinemia was the cause of the case of hepatic cirrhosis, although this diagnosis was considered the most likely explanation for the histological appearances. The value of routine bacteriology and virology on all cases is perhaps more debatable, but accurate serology would have been helpful in the case of syphilis, and microbiology would be of interest in the infant deaths from pneumonia and meningitis. However, despite these methological difficulties, this research provides important evidence on which to base preventative strategies.

The pattern of perinatal deaths is similar to that described in perinatal mortality reports from the developed world [2], with $28 \%$ of the deaths being attributable in the past to the effects of prematurity. Infection and anoxia accounted for the rest, with the exception of one chromosome abnormality. In less developed countries [3], the proportion of normally formed macerated stillbirths is greater, and the under-representation of stillbirths in our series may well have disorted the results. In this series, the proportion of deaths diagnosed as being due to perinatal asphyxia (14\%) is also lower than expected from a poor community with inadequate health care. For comparison, the Jamaican perinatal survey [4], using the Wigglesworth classification, identified $44 \%$ of perinatal deaths as attributable to intrapartum asphyxia. The reason for the low rate of asphyxia in our study is probably that the majority of births from women in Felipe Camarão took place in the teaching hospital, and received a good standard of obstetric care.

Antenatal care could theoretically have prevented the maternal and fetal deaths from hypertension, and professional assistance at the delivery may have been able to change the outcome for case 12. Early identification and treatment of maternal syphilis may have been able to modify the effects in the infant in case 3 . In the rest of the cases, 
Table 3. Infant deaths

\begin{tabular}{|c|c|c|c|c|}
\hline Case & $\begin{array}{l}\text { Age (months)/ } \\
\text { sex }\end{array}$ & Symptoms & Principal causes of death & Other factors \\
\hline 1 & $11 / \mathrm{F}$ & $\mathrm{F}$ & $\begin{array}{l}\text { Bronchopneumonia }+ \text { pericarditis } \\
\quad+\text { enteritis }\end{array}$ & Marasmus \\
\hline 2 & $1 / \mathrm{M}$ & F, C, V, D & $\begin{array}{l}\text { Purulent } \\
\text { meningitis }+ \text { bronchopneumonia }\end{array}$ & - \\
\hline 3 & $12 / \mathrm{F}$ & F, Dy, Cgh & $\begin{array}{l}\text { Bronchopneumonia + Löeffler syn- } \\
\text { drome }\end{array}$ & Ascariasis \\
\hline 4 & $5 / \mathrm{F}$ & $\mathrm{D}$ & Bronchopneumonia + dehydration & Marasmus + scabies \\
\hline 5 & $6 / \mathrm{M}$ & $\mathrm{D}, \mathrm{Dy}$ & Bronchopneumonia + dehydration & Kwashiorkor/marasmus + ascariasis \\
\hline 6 & $7 / \mathrm{M}$ & F, V, Dy & $\begin{array}{l}\text { Candida enteritis and } \\
\text { peritonitis }+ \text { purulent meningitis }\end{array}$ & Marasmus \\
\hline 7 & $11 / \mathrm{F}$ & F, D, Cgh & Bronchopneumonia + dehydration & Marasmus \\
\hline 8 & $5 / \mathrm{M}$ & F, C, Cgh & $\begin{array}{l}\text { Purulent } \\
\text { meningitis }+ \text { bronchopneumonia }\end{array}$ & Marasmus \\
\hline 9 & $12 / \mathrm{F}$ & F, V, D & Enteritis + dehydration & Marasmus + scabies \\
\hline 10 & $2 / \mathrm{M}$ & $\mathrm{V}, \mathrm{D}$ & Candida enteritis + bronchopneumonia & Marasmus \\
\hline 11 & $11 / \mathrm{F}$ & F, V, D & $\begin{array}{l}\text { Lymphocytic } \\
\text { pneumonia }+ \text { enteritis }+ \text { dehydration }\end{array}$ & Kwashiorkor/marasmus \\
\hline 12 & $8 / \mathrm{F}$ & $\mathrm{F}, \mathrm{Cgh}$ & $\begin{array}{l}\text { Bronchopneumonia }+ \text { pleural } \\
\text { empyema }\end{array}$ & Marasmus \\
\hline 13 & $4 / \mathrm{F}$ & F, Dy & $\begin{array}{l}\text { Lymphocitic pneumonia }+ \text { lymphocytic } \\
\text { meningitis }\end{array}$ & Marasmus \\
\hline 14 & $2 / \mathrm{M}$ & F, V, D & Bronchopneumonia + enteritis & - \\
\hline 15 & $4 / \mathrm{F}$ & F, D & Dehydration + enteritis & Kwashiorkor/marasmus \\
\hline 16 & $2 / \mathrm{F}$ & V, D & Dehydration & Marasmus \\
\hline 17 & $12 / \mathrm{F}$ & $\mathrm{V}, \mathrm{D}$ & Dehydration + enteritis & Marasmus + ascariasis \\
\hline 18 & $4 / \mathrm{F}$ & $\mathrm{V}, \mathrm{D}, \mathrm{Dy}$ & Cystic fibrosis + dehydration & Marasmus + candida esophagitis \\
\hline 19 & $12 / \mathrm{F}$ & $\mathrm{V}, \mathrm{D}$ & Dehydration & Kwashiorkor/marasmus + ascariasis \\
\hline 20 & $8 / \mathrm{M}$ & V, D & $\begin{array}{l}\text { Bronchopneumonia }+ \text { pseudomem- } \\
\text { branous colitis }+ \text { dehydration }\end{array}$ & Kwashiorkor/marasmus \\
\hline 21 & $6 / \mathrm{M}$ & F, Dy, Cgh & $\begin{array}{l}\text { Endocardial fibroelastosis + urinary } \\
\text { infection }\end{array}$ & Marasmus \\
\hline 22 & $3 / \mathrm{F}$ & F, V, D, Cgh & Hepatic cirrhosis (tyrosinemia?) & Marasmus \\
\hline 23 & $6 / \mathrm{M}$ & F, C, V, Cgh & $\begin{array}{l}\text { Purulent } \\
\text { meningitis }+ \text { bronchopneumonia }\end{array}$ & - \\
\hline 24 & $8 / \mathrm{M}$ & V, D, Dy & Dehydration + bronchopneumonia & Marasmus \\
\hline 25 & $11 / \mathrm{M}$ & Dy, Cy & $\begin{array}{l}\text { Transposition of the great } \\
\text { arteries }+ \text { bronchopneumonia }\end{array}$ & - \\
\hline
\end{tabular}

however, the mother either attended antenatal care or went into preterm labor for no obvious reason. The most likely cause of unexpected preterm labor in this population is ascending infection, but lack of facilities prevented accurate diagnosis. This contrasts with national data from neighboring Argentina [5], which estimated that $74 \%$ of neonatal deaths could have been partially or totally avoided by improved preventive, diagnostic, or treatment services.

The striking features of this series of infant deaths are the predominance of infection, particularly bronchopneumonia, as the final cause of death, and the prevalence of underlying malnutri- 


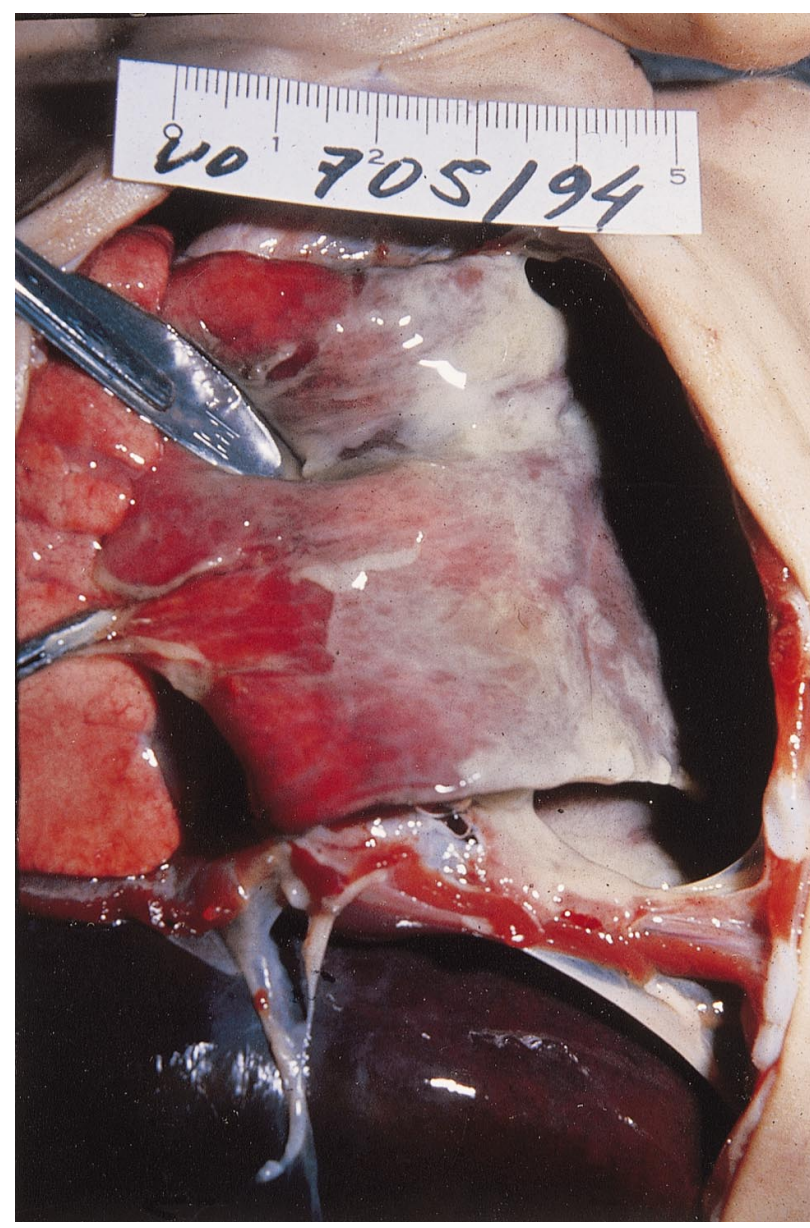

Figure 1. Postmortem view of lungs of case 12, showing bronchopneumonia and pleural empyema.

tion. The underlying reasons for malnutrition include the poverty of the community, the lack of exclusive breast-feeding, and local weaning practices. Appropriate identification and early treatment of malnutrition may have favorably influenced the outcome for these cases. It is also obvious from our series that half of the infants who died had either not been breast fed at all, or breast fed for less than a month, and it is likely that health promotion and community support of breastfeeding would reduce this mortality [6].

The causes of infant death in our study in Brazil are similar to those found in populationbased studies in North Africa [7] and India [8] and contrast with reports from the developed world [9], where sudden infant death syndrome, accidents, and the complications of prematurity are most prominent. In our series, there were no cases of sudden infant death syndrome, a condition that

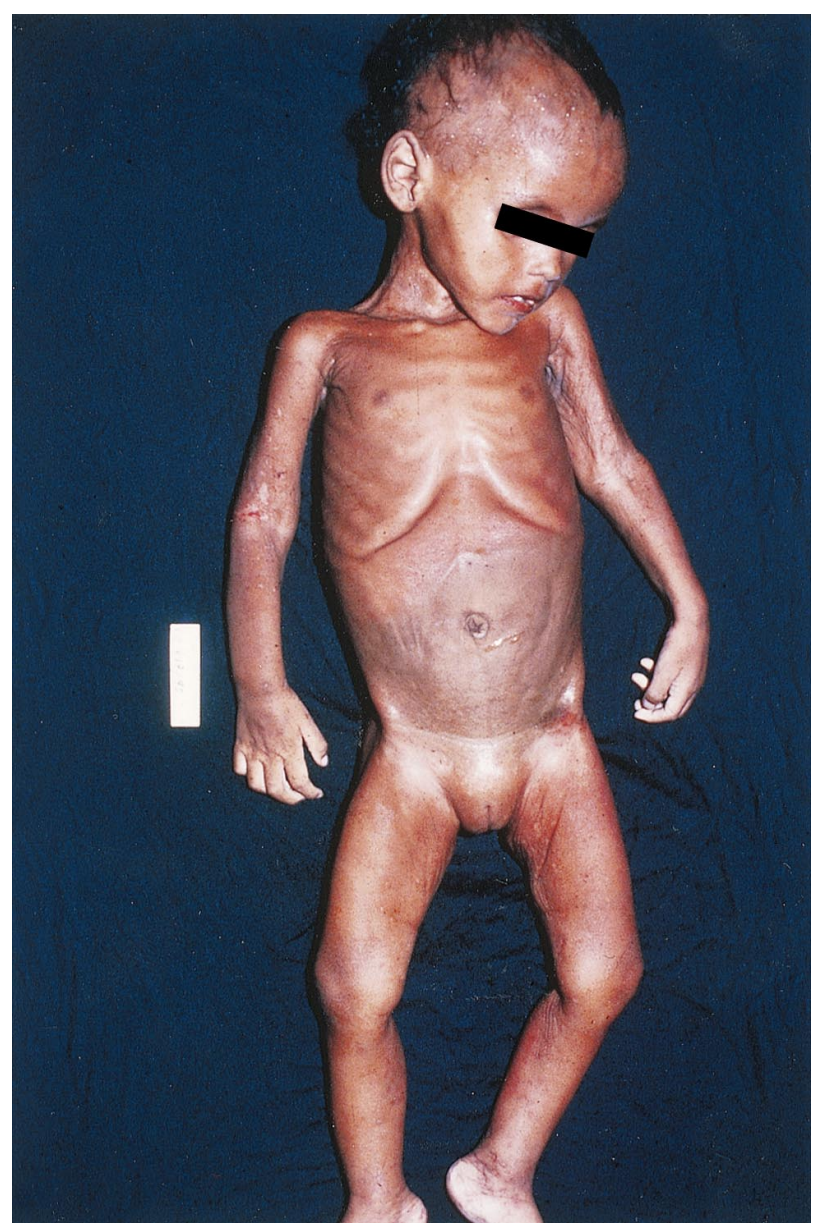

Figure 2. Case 19, a girl of 12 months of age who died of dehydration and malnutrition, with fatty change in her liver at postmortem.

appears to be rare in Brazil. Deaths due to accidents were not included in this series, as the autopies are undertaken in the medicolegal service. One death due to an accident was, however, registered in 1994. The complications of prematurity, which were prominant among perinatal deaths in our series, were not recognized as contributing to the infant deaths.

There are few published reports on the causes of infant mortality in Brazil; UNICEF [10], in a report on the situation of children in the state of Rio Grande do Norte, presented data from 1986 showing overall infant mortality across the state to be $84 / 1000$, when the Brazilian average was 51/ 1000. In 1963, in Recife, a study [11] reported a series of infant deaths, with a predominance of kwashiorkor. This city is near Natal, and their results are very similar to ours 30 years later. In 1978, A. C. Ribeiro [12] are reported a study on 
infant mortality in Marilia, São Paulo and showed an infant mortality rate of $67 / 1000$, with a pattern of causes of death similar to ours. A review [13] of infant deaths from Belo Horizonte, in the Southeast of Brazil, found that pneumonia, diarrhea, and malnutrition dominated, and discovered inaccuracies in registered causes of death, with $44 \%$ of certificates judged to be incorrect. The problems of death registration and certification can only be overcome with a multifaceted approach, educating the population, community health workers, and doctors of the importance of registration and accurate identification of cause of death, together with the provision of appropriate facilities to undertake the autopsies.

In conclusion, this series of autopsies, based on a geographically defined population in Northeast Brazil has shown that perinatal mortality is due to complications of prematurity and specific infections, with only $14 \%$ being due to asphyxia. Infant mortality is dominated by acute respiratory and diarrheal infection, but underlying malnutrition was present in the majority of cases. The Pró-Natal Project will use these data to design preventative interventions, prioritizing prenatal care, the promotion of breast-feeding, the earlier identification and treatment of malnutrition, and improved treatment of acute infections, to reduce the mortality in this poor urban community.

\section{ACKNOWLEDGMENTS}

We thank the pathologists and technicians who assisted with the postmortem examinations, and especially Dr. Carlos Cesar Formiga Ramos, Director of the S.V.O. The Pró-Natal Project is sup- ported by the British Council, D.F.I.D., the Wellcome Trust, CAPES, CNPq, and the Municipal and State Secretariats of Health in Natal.

\section{REFERENCES}

1. Wigglesworth JS. Monitoring perinatal mortality. A pathophysiological approach. Lancet 1980;ii:684-686.

2. Keeling JW, MacGillivray I, Golding J, et al. Classification of perinatal death. Arch Dis Child 1989;64:1345-1351.

3. Amar HSS, Maimunah AH, Wong SL. Use of Wigglesworth pathophysiological classification for perinatal mortality in Malasia. Arch Dis Child 1996;74:F56-F59.

4. Coard K, Codrington G, Escoffrey C, Keeling JW, Ashley D, Golding J. Perinatal mortality in Jamaica 1986-1987. Acta Paediatr Scand 1991;80:749-755.

5. Agrupamiento de causas de muerte de menores de un ano. Boletin del Programa Nacional de Estadisticas (Argentina) 1990;1:1-16.

6. Vitoria CG, Smith PG, Vaughan JP. Evidence for protection by breast feeding against infant deaths from infectious disease. Lancet 1987;ii:319-321.

7. Bendib A, Dakker N, Lamdjadani N. Factors associated with neonatal, infant and child mortality. Results of a national survey in Algeria. Arch Fr Pediatr 1993;50:741747.

8. Reddaiah VP, Kapoor SK. Socio-biological factors in under five deaths in a rural area. Indian J Pediatr 1992;59:567571.

9. Confidential Enquiry into Still Births and Deaths in Infancy. CESDI 1993 Annual Report. London: Department of Health, 1995.

10. Governo do Estado do Rio Grande do Norte e Unicef. A situaçao da criança no Rio Grande do Norte. Natal: UNICEF, 1990.

11. Barros Coelho R, Coutinho Abath E, Barbosa A, et al. Aspectos etiopatogênicos e morfológicos da sindrome pluricarencial da infância no Recife. Rev Bras Malariolog Doenças Trop 1963;1.XV:67-129.

12. Ribeiro AC. Mortalidade infantil no Marilia. MSc thesis, University of São Paulo, 1978.

13. Mendoça EF, Goulart EM, Machado JA. Reliability of the declaration of underlying causes of infant deaths in the metropolitan region of Southeastern Brazil. Rev Saude Publica 1994;28:385-391. 